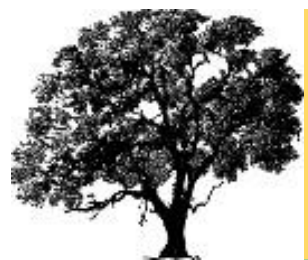

Eurasian Journal of Forest Science

2021 9(3): 160-174

http://dergipark.org.tr/en/pub/ejejfs

\title{
Economic analysis in social responsibility projects of forest villages (case of the western Mediterranean region)
}

\author{
Ufuk COŞGUN ${ }^{1, *}$ (iD \\ 1," Forest Policy and Management Dept. of Forest Faculty, Karabuk University, 0078 Karabuk, TURKEY \\ Corresponding author: ufukcosgun@karabuk.edu.tr
}

\begin{abstract}
In Turkey, the population living around forest areas is significantly affected by forestry activities. There are 21 thousand forest villages and 7 million forest villagers living in these forest villages within the 22.9 million ha forest area. In other words, one out of every three people living in rural areas is a forest villager.

Daily life activities of forest villagers living together with forest areas can cause pressure on forests. GDoFV by various development projects to reduce the impacts of pressures on forest areas of forest villagers have been implemented. This improvement loans are two groups, including for economic and social purposes.

GDoFV only makes cost-benefit analysis for social projects. Does not apply any other economic analysis. Water Heating with Solar Energy Systems (Solar Power Plant) project is a project implemented by GDoFV social purposes. The aim of the SPP projects is to reduce the firewood consumption of the forest villagers. This case study aimed to evaluate the economic analysis of SSP projects implemented to reduce the forest villager's consumption of firewood. In the forest villages of the Western Mediterranean Region, 100 forest villages were sampled from 152 forest villages and 629 forest villagers where SPP application was made.
\end{abstract}

Key Word: Solar Power Plant for Forest villgers, economic analysis, forest villages

\section{Introduction}

With the "Forest Law" numbered 6831 enacted in 1956 and still in force in Turkey, the population living in or adjacent to forest areas in rural areas is defined as "forest villagers". In the process that has passed since the establishment of our Republic; There have been significant changes in the rural structure in Turkey. In the beginning, about $75-80 \%$ of the population lived in rural areas, but today this situation has changed. In this period, it was considered very important to improve the economic level of the rural population and to create a rapid rural development. With these approaches, five-year country development plans were created in the 1960s. In the 1970s, the Ministry of Rural Affairs was established and the development problem of the population in rural life began to be addressed more concretely. This was followed by the establishment of the "General Directorate of Forest Village Affairs" (GDoFVA) under the Ministry of Forestry in the second half of the 1970s (Coşgun, 2008).

In this period, forest villagers; utilization levels of forests and pressure on forestry organization etc. effects have been studied. (DPT, 1970; DPT, 1971; Anı1, 1973; Duruöz,1975; Duruöz ve ark., 1976; İstanbullu, 1978). Levels of utilization of forests, which are natural habitats of forest villagers, and development opportunities of forest villagers; It formed the focus of the studies carried out in the 1980s. GDoFVA District Development Plans; It is an important work that started in the late 1970s and was completed in this period. Potential development opportunities have been determined on the basis of districts for the development of forest villagers at the country level. The necessary plans for development were determined 
by expert teams. Investigations on these works of GDoFVA; forestry has been publicly discussed (Geray ve Acun, 1980; Geray, 1982; Tarakl1, 1982; Acun, 1983; Çağlar, 1986; Çağlar, 1987).

The social and economic project applications implemented by GDoFVA and the studies on the evaluation of the socio-economic structures of the forest villagers were examined in various dimensions in the 1990s (Tolunay, 1992; Türker ve Toksoy, 1992; Türker, 1992; Anonym, 1997; Gümüş, 1993; Gökçe ve ark., 1998; Tolunay, 1998; Özkurt, 1998). The effects of GDFVA project implementations on forest villagers and their contribution to the development of forest villagers, as well as the evaluation of the results of the implemented project studies, are the subjects that were especially examined in the 2000s (Tolunay ve ark., 2002; Daşdemir, 2003; Coşgun, 2005; Tolunay ve Korkmaz, 2005; Coşgun ve ark., 2007; Uzun, 2008; Coşgun ve ark., 2009; Önal, 2010; Okutucu ve ark., 2012; Korkmaz ve Alkan, 2014; Coşgun, 2016; Daşdemir, 2016; Coşgun, 2017; Daşdemir, 2017).

Forest villages and people living in these villages constitute the disadvantaged group in rural areas. When we come to the present day from the establishment of our republic, the structure of the population has also changed. Today, 30\% of the population lives in rural areas and 70\% in urban areas (Anonym, 2007, TOD, 2019). However, the population of forest villages has an important place in the rural population. $1 / 3$ of the population living in rural areas are forest villagers.

Turkey has 22,9 mil ha forest area (Anonym, 2020). The ratio of forest land to Turkey country area is $29,4 \%$. There are found 21 thousand forest village in Turkey and 7 mil forest villages population live within and around.

Therefore, the works to be carried out on forest areas directly affect the forest villagers. In order to prevent the forest villagers from being adversely affected, different individual and cooperative loans have been developed by GDoFVA. It is aimed that the forest villagers will be less affected by various forestry activities with social and economic credit applications. Studies for the development of forest villagers; Since its establishment, an understanding has prevailed that it should be carried out through GDoFVA. However, sufficient resources have not been provided to enable GDoFVA to fulfill this function. Due to the different organizational models in the process from its establishment to the present; efficient works have not been carried out (Coşgun, 2020). GDoFVA 's organizational structure got smaller in different organizational structures; It has turned into a head of Department GDoFVA, and has had to carry out its work with this structure.

In the establishment of the Ministry of Forestry and Water Affairs in 2011; It was reduced from the General Directorate level to the Department of Forest Village Relation level (DoFVR) (Coşgun, 2016). Other forms of organization in this practice and process, due to the inability to establish a link between the functions attributed to DoFVR and the resources allocated; DoFVR has received serious criticism for the works it has implemented and/or failed to implement.

The main purpose of DoFVR is; to reduce or prevent the exposure of forest villagers who are subject to various restrictions due to forestry practices, and thus to reduce or eliminate the negative pressures of forest villagers on forests. To this end; DoFVR developed credit projects for economic and social purposes for forest villagers. To forest villager families; economic and social loans and to forest village cooperatives; It is aimed to develop the forest villagers by providing loans with economic content (Coşgun, 2020).

Since the beginning of the 2000s has applied, the Solar Water Heater Systems (Solar Power Plant) Water Heating Project is one of the social projects initiated by DoFVR and rapidly gaining popularity.SPP project; aims to reduce the forest villager's consumption of firewood. Various studies have been carried out on the amount of wood savings realized as a result of the implementation of the project, which started to be implemented since 2005 and became widespread rapidly (Önal, 2010; Önal ve Bekiroğlu, 2011; Okutucu ve ark., 2012; Coşgun, 2017). On the other hand, there have been social and economic researches 
that firewood consumption for rural area people (Win et al, 2018; Johnson et al, 2010; DeFries and Pandey, 2010; Kreşten et al, 1998; DeMontalembert and Clement, 1983; Ullah et al, 2021; Awah, 2021).

Forest villagers consume firewood in various activities (cooking, water heating, bathing, heating, etc.) throughout the year. It buys some of its wood needs from forest management directorates in return for money. In addition, it evaluates various wood wastes resulting from its own vineyard and garden works and obtains some of it illegally from the forest.

Unfortunately, there is no regular monitoring system for social and economic projects carried out by GDoFVA, except for project repayments. After social and economic project implementations, in the socioeconomic structure of the forest villagers; It is not known how much progress has been made. Studies on the subject are of local or regional dimensions. A research study that will make a general evaluation of Turkey has not been carried out.

An important effect of forest villagers' use of wood for fuel is on climate change. The consumption of firewood causes a decrease in existing carbon stocks. On the other hand; With the help of the implemented SPP project, fuelwood savings and contributions to the country's carbon stocks can also be determined. Studies on carbon stocks and their calculations are developing rapidly in Turkey.

In GDoFVA social purpose project investments, economic analysis is not performed. Only the determination of the benefit-cost ratio $(\mathrm{B} / \mathrm{C})$ is considered sufficient. But Net Present Value and Internal Profitability Ratio; emerges as a more decisive economic analysis. Therefore, it is necessary to ensure that these three elements are included in the general economic analysis, even if they are social projects.

The aim of the study; GDoFVA is the evaluation of social-purpose project supports by performing economic analysis. As a result of the project implementation, It is the comparison of the economic analysis made according to the realization data obtained and the economic analysis at the beginning of the project. The scope of the project; These are the forest villages in the provinces of Antalya, Burdur and Isparta where the SPP project is implemented in the Western Mediterranean Region (Figure, 1). 


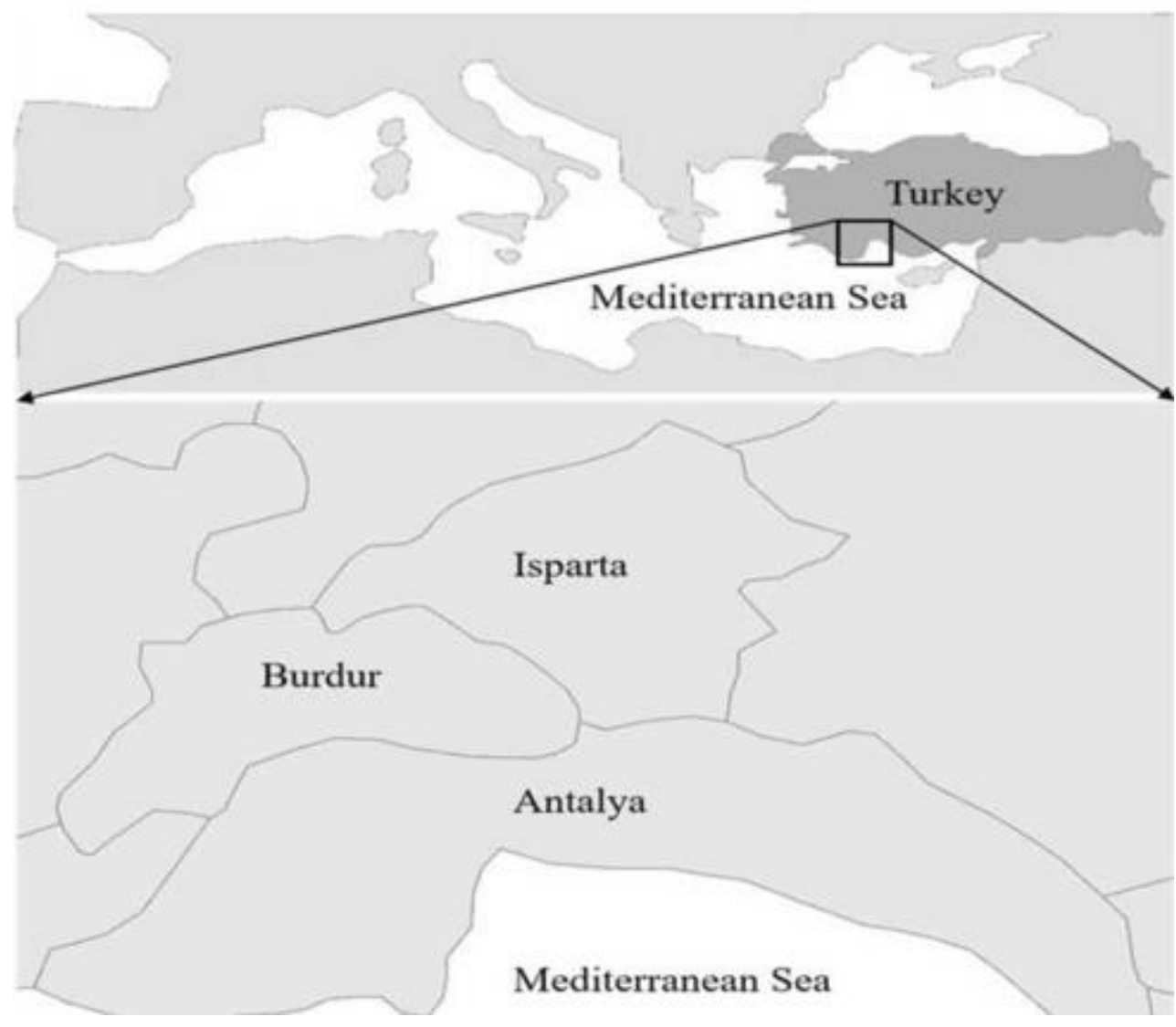

Figure 1. Study area.

Families in forest villages benefiting from the SPP project did not achieve the expected level of savings in annual wood consumption. For this reason, it has been observed that there are differences between the calculated economic analysis values.

SPP application is a technology based on obtaining energy from sunlight. The energy emitted by the Sun and reaching our Earth; It is the radiation energy released by the fusion process in the core of the Sun. The conversion of hydrogen gas in the sun to helium is due to the fusion process. The intensity of solar radiation outside the Earth's atmosphere; roughly constant at $1370 \mathrm{~W} / \mathrm{m} 2$; however, it varies between $0-1100 \mathrm{~W} / \mathrm{m} 2$ values on earth. Even a small portion of this energy coming to Earth is many times more than the current energy consumption of humanity. Studies on benefiting from solar energy; Especially after the 1970s, it gained momentum, Solar energy systems showed a decrease in technological progress and cost, Solar energy has established itself as an environmentally clean primary energy source (Gökyel and Ulusoy, 2016).

The amount of solar radiation falling on the world is much more than the energy demand of the world. The rays reaching the earth's surface are 10,000 times more than the total energy consumption. Annual average unit, amount of solar energy per square meter; It is $1,000 \mathrm{kWh}$ in Europe and 1,800 kWh in the Middle East. According to the studies, if approximately $0.71 \%$ of the European surface is covered with solar panels; All the energy that Europe needs will be met. According to a study conducted by the IEA (International Energy Agency), if 4\% of the world's deserts are covered with solar panels, the primary energy needs of the whole world can be met (Gökyel and Ulusoy, 2016).

There are two basic ways to use solar energy. The first is to generate energy using traditional methods with 
the help of turbines by making use of the sun's heat. The other method is photovoltaic panels. Photovoltaic panels are semiconductor technologies that directly convert sunlight into electrical energy. The energy obtained by using photovoltaic panels in the world; agriculture, housing, industry, greenhouse gas emissions, etc. that is, their effects on climate change are examined. There are various studies on the economic and social analysis of the effects arising from the using panels in various sectors (Wang, 2006; Cuce et al, 2016; Akinyele et al, 2015; Spertino et al, 2013; Odeh et al, 2006; Campana et al, 2015-a; Campana et al, 2015-b; Björnsen, et al, 2017; Solovy et al, 2018; Solovy et al, 2019).

In addition to the economic and environmental benefits provided by the choice of the renewable energy field, it has gained importance in terms of social benefits as it offers new business opportunities. In the result of preferring renewable energy investments; It is being created employment potential in project development, construction- and assembly, operation and maintenance-repair processes. In addition, employment is created in the production of machinery, materials and industrial products required by the renewable energy sector and in the development of workforce skills (Y1lmaz, 2014). In our country, plans and forecasts regarding employment in the renewable energy sector have been created. According to different scenarios. It is seen that the annual employment in solar energy will vary between 5,0008,000 people/year. In this case, it is predicted that biomass energy production can vary between 8001300 people/year (Y1lmaz, 2014). Annual water heating capacity by using solar energy; In China, it is 2 times more than in Europe and 4 times more than in North America. The increase using of solar energy system and water heating systems in China; It is perceived as a social project that will contribute to social sustainable development by reducing electricity consumption (Wang, 2006). As a result of the evaluation of central heating (petroleum products), tube usage, kerosene, electricity usage and solar energy systems with the Analytical Hierarchy process; It has been determined that solar water heating system is the cheapest type of heater. In conclusion, we can say that the solar water heating system is the most desirable system for use in Jordan (Mohesen, and Akash, 1997).

\section{Material and Method}

Among the social projects implemented by GDoFVA in recent years; "Reduction of Fuel Wood Consumption" (RoFWC) projects take an important place. Among these projects, the most widely implemented and continued to be implemented; It is a water heating (SPP) project with solar energy systems. This study; It covers the forest villages where the "Solar Water Heating (SPP) Project" is implemented in the provinces of Antalya, Burdur and Isparta in the Western Mediterranean Region.

The material of the study; It is the face-to-face survey data conducted with families living in forest villages in the provinces of the Western Mediterranean Region.

In the questionnaire, questions about the social and economic structures, and the annual firewood consumption, were asked. These questions have been age, gender, population distribution by households, educational status, social security status of families, basic livelihoods, share of firewood cost in family income, etc. In addition, the questions of where and in what quantities the amount of wood consumed as fuel is obtained are also included.

A questionnaire was applied in 29 of 37 villages where SPP implementation was carried out in Antalya. A survey was conducted in 30 of 50 forest villages in Burdur and 100 out of 152 villages in Isparta, 
respectively. A survey was conducted in 100 of the 152 villages where SPP implementation was carried out in the region, and $66 \%$ were sampled. A survey was conducted with 629 households by sampling $18 \%$ of 3447 households in forest villages where SPP application was carried out throughout the region (Coşgun and Güler, 2015).

Even in the socially-oriented projects implemented for forest villagers, there is an economic burden. It is vital to know the net present value and especially the internal rate of return. Only the benefit-cost ratio is included in the economic analysis of the socially oriented GDFVA projects implemented for forest villagers. However, this approach is not sufficient. In this study, the evaluation of social benefits is not included since the economic dimensions of GDFVA social-oriented projects are taken into account because this approach requires another assessment.

Socially oriented SPP projects implemented by GDFVA have been applied to more than 140 thousand forest villagers in Turkey. It is important that only the benefit-cost ratio is included and no other economic analyses are included.

In the calculation of the benefit-cost ratio, the variability of the amount of firewood and the price of the firewood can show the project positively. whereas the main indicator is economic analysis, net present value, and especially the internal rate of return

\section{Discussion}

\subsection{Economic Analysis of SPP Application from the Perspective of Forest Villagers}

In the economic analysis of SPP applications, project evaluation criteria such as Net Present Value and Internal Profitability Ratio are used. Indeed, these criteria are suitable for analysis within the scope of commercial profitability. While making the economic analysis of the SPP application, the approach to be followed when it is desired to analyse the forest villagers based on what they get from this work is commercial profitability analysis.

The calculations of Net present value; Internal Profitability Ratio was preferred in the study due to its limitations such as being affected by the size of the project and the need for an externally determined discount rate. However, as mentioned in the literature, in order to make these analyzes, it is necessary to accept a technical life in the SPP application and calculate the costs and revenues on a yearly basis. Considering the information obtained during the research;

- SPP applications have a technical life of 15 years,

- 1 unit of SPP is purchased by GDFVA for 1200 TL in cash from the seller company on behalf of the villager and installed on the other hand, the villagers pays their loan in 3 years without paying any interest (400 TL+400 TL+400 TL)

- Before the SPP, the villagers consumed 4 LPG gas per year and the total cost $(4 \times 82)$ corresponded to $328 \mathrm{TL} / y e a r$, with the use of SPP, the villager saves $61.44 \%$ in annual LPG consumption and it is (328X0.6144) 201,52 TL/year in value

- The forest administration procures $25 \%$ of all fuel wood needs of the villagers from their own fuel allocations, and villagers for this, pays 41,3 TL/ster in Article 31 villages, while Article 32 villages pay 49,56 TL/ster (average 45,34 TL), In case of installing SPP to the households; from the fact that there is no need to use a total of 5 ster of wood per year and therefore the villager's personal fuel wood payments; saved from paying a total of 56,79 TL ( 5 X 0,25 X 45,43), 
- The effect of fuel wood and LPG consumption savings will be evident in the first year,

- It is assumed that the SPP application will need maintenance and repair costs during its useful lifetime and in the 10th year, and a budget of $400 \mathrm{TL}$ will be needed for this requirement.

Considering these assumptions; The income and expense relationship created by the SPP application for the villagers is shown in Table 1.

Table 1: Evaluation of the SPP Application in terms of Forest Villagers (income-expense)

\begin{tabular}{cccccccc}
\hline YEARS & EXPENSE & INCOME & NET & \multicolumn{3}{c}{ Present Value Calculated Discount Rate (I) } \\
& & & & $10 \%$ & $20 \%$ & $30 \%$ & $40 \%$ \\
\hline 1 & 400 & 258,31 & $-141,69$ & $-128,8091$ & $-118,0750$ & $-108,9923$ & $-101,2071$ \\
2 & 400 & 258,31 & $-141,69$ & $-117,0992$ & $-98,3958$ & $-83,8402$ & $-72,2908$ \\
3 & 400 & 258,31 & $-141,69$ & $-106,4538$ & $-81,9965$ & $-64,4925$ & $-51,6363$ \\
4 & 0 & 258,31 & 258,31 & 176,4292 & 124,5708 & 90,4415 & 67,2402 \\
5 & 0 & 258,31 & 258,31 & 160,3902 & 103,8090 & 69,5704 & 48,0287 \\
6 & 0 & 258,31 & 258,31 & 145,8093 & 86,5075 & 53,5157 & 34,3062 \\
7 & 0 & 258,31 & 258,31 & 132,5539 & 72,0896 & 41,1659 & 24,5045 \\
8 & 0 & 258,31 & 258,31 & 120,5035 & 60,0747 & 31,6661 & 17,5032 \\
9 & 0 & 258,31 & 258,31 & 109,5487 & 50,0622 & 24,3585 & 12,5023 \\
10 & 400 & 258,31 & $-141,69$ & $-54,6276$ & $-22,8837$ & $-10,2779$ & $-4,8985$ \\
11 & 0 & 258,31 & 258,31 & 90,5361 & 34,7654 & 14,4133 & 6,3787 \\
12 & 0 & 258,31 & 258,31 & 82,3055 & 28,9712 & 11,0872 & 4,5562 \\
13 & 0 & 258,31 & 258,31 & 74,8232 & 24,1427 & 8,5286 & 3,2544 \\
14 & 0 & 258,31 & 258,31 & 68,0211 & 20,1189 & 6,5605 & 2,3246 \\
15 & 0 & 258,31 & 258,31 & 61,8374 & 16,7657 & 5,0465 & 1,6604 \\
\hline TOTAL NET PRESENT VALUE (NPV) & 815,7683 & 300,5265 & 88,7512 & $-7,7732$ \\
\hline
\end{tabular}

The years column of Table 1; The economic life of the SPP application, and the expenses and income columns represent the annual income and expenses that are expected to occur for the villagers according to the above assumptions and research findings.

As it is known, Internal Profitability Ratio of return is the discount rate that makes the net present value (NPV) zero, and in order to calculate it, it is necessary to calculate the net present value with an interactive approach. These calculations are shown in Columns 5, 6, 7 and 8 of Table 1. NPV account;

The formula $\mathrm{Ko}=\mathrm{Kn} / 1.0 \mathrm{p}^{\mathrm{A}} \mathrm{n}$ is used. Ko in the formula; represents the present value. Kn shows the value of the income, expense or net surplus in the $\mathrm{n}$. year of the project, which will be discounted to today. $\mathrm{p}$; shows the discount rate (Balçık, 2003).

As it can be understood from the examination of Table 1, the Internal Profitability Ratio (IPR) of SPP applications is greater than $30 \%$ but less than $40 \%$. Based on this range and using the formula IPR $=r 1+$ $(\mathrm{PV}(\mathrm{r} 2$ - r1 $) /(\mathrm{PV}+\mathrm{INVI}))$, the internal rate of return can be calculated.

In the formula;

r1; The discount rate that makes the NPV positive, 
r2; The discount rate that makes the NPV negative,

$\mathrm{PV}$; positive present value and

INVI is the absolute value of the obtained negative present values means.

The Internal Profitability Ratio $($ IPR $)=30+(88,7512(40-30) /(88,7512+7,7732)=39,29$ are available as.

According to the calculations, the annual return of the capital provided to the establishment of the SPP by the forest villagers with the opportunities provided by GDoFVA, it is at the level of $39.29 \%$ and compared to the alternative investment opportunities of the market, it should be considered as a viable venture.

For social projects, only the Benefit Cost Ratio (B/C) is calculated in the GDoFVA approach. In this calculation, a depreciation of $1 / 6$ of the cost of the system is used as an expense. As income; With the project, 5 sters of firewood saving and its cost are taken into consideration. However, the saving amount of 5 ster of firewood here is evaluated according to market prices. However, forest villagers obtain their firewood at a different price from the market (at a lower price than the market) in accordance with the forest law no. 6831 .

In general, the Benefit Cost Ratio (B/C) made by considering the market price of the SPP projects implemented by GDoFVA varies between 1.30-1.80. However, this ratio is 0.77 according to the data above.

\subsection{Economic Analysis of SPP Application from the Perspective of GDoF}

It is not sufficient to subject the SPP application to an economic evaluation in terms of the forest villagers, who are the beneficiaries of the facility. A similar analysis needs to be done for the public or GDoF as well. The analysis of the contribution of a project to the country's economy is called national profitability analysis and different evaluation criteria are preferred in this context.

In the National Profitability analysis of the projects while it is possible to use criteria such as National Benefit- Cost analysis, Value Added analysis, Capital Output Ratio, Capital Employment Ratio. In addition it is also possible to develop special criterias related to current economic problems. For example; Foreign Trade Effect and Current Account Deficit Effect etc.

For the SPP application, it is possible to make an analysis based on GDoF, which is currently DoFVR depends on and with the national cost-benefit approach. However, there are problems in defining and measuring costs, defining and measuring benefits, deciding the useful life, and determining the discount rate in benefit-cost analysis.

- For 1 unit of SPP, 1200 TL cash payment will be made by the administration from own resources, the payment will be made in advance present time and the repayment of this payment will be taken from the villagers in three equal installments without any interest.

- While forest villagers benefit from SPP, it is distributed equally to the 31 st and 32nd article villages and it will eliminate the allocation of 1 ster of firewood per unit per year. Therefore, GDoF will lost an average of 45,43 TL/year of from fuelwood allocation income starting from the first year when the SPP is installed. 
On the other hand, by selling 1 ster of wood saved for one unit of SPP, a sales income of $105 \mathrm{TL} / \mathrm{ster}$ will be possible,

- Although it is known that GDoF does not evaluate its own resources in the money market as if it were a financial institution, it is assumed that if it evaluates its own resources at the current market interest rate, GDoF can earn an annual gain of $13 \%$. Therefore the discount rate can be taken as $13 \%$,

- According to these assumptions, the benefits and costs for GDoF during the economic life of the SPP are shown in Table 2.Using the research findings;

- GES implementation will provide benefits to GDoF for 15 years.

Table 2: Analysis Values for GES Application for GDoF

\begin{tabular}{ccccc}
\hline Years & Total Benefits TL & Total cost TL & Present Value of & Present Value of Costs \\
\hline 0 & 0 & 1200 & 0 & 1200 \\
1 & 105 & 45,43 & 92,92 & 40,20 \\
2 & 505 & 45,43 & 395,49 & 35,58 \\
3 & 505 & 45,43 & 349,99 & 31,49 \\
4 & 505 & 45,43 & 309,73 & 27,86 \\
5 & 105 & 45,43 & 56,99 & 24,66 \\
6 & 105 & 45,43 & 50,43 & 21,82 \\
7 & 105 & 45,43 & 44,63 & 19,31 \\
8 & 105 & 45,43 & 39,50 & 17,09 \\
9 & 105 & 45,43 & 34,95 & 15,12 \\
10 & 105 & 45,43 & 30,93 & 13,38 \\
11 & 105 & 45,43 & 27,37 & 11,84 \\
12 & 105 & 45,43 & 24,22 & 10,48 \\
13 & 105 & 45,43 & 21,44 & 9,28 \\
14 & 105 & 45,43 & 18,97 & 8,21 \\
15 & 105 & 45,43 & 16,79 & 7,26 \\
\hline \multicolumn{7}{r}{} & Total & B/C ratio & & 1493,59 \\
\hline
\end{tabular}

Calculations in the Present Value of Benefits and Costs columns in Table 2 are made on based the 13\% discount rate using the present value formula given above. Considering the total benefits and costs in Table 2 , it is seen that the benefit-cost ratio $(\mathrm{B} / \mathrm{C})$ is 1.014 .

$\mathrm{B} / \mathrm{C}$ ratio greater than one means; he states that the benefits provided by the SPP application to the administration in the fifteen-year period are higher than the costs incurred by the administration. However, the fact that the ratio is very close to one reveals that there is an equivalence.

This indicates that the administration is looking for ways to increase the $\mathrm{B} / \mathrm{C}$ ratio with a better design.

a) Lowering the initial installation costs of the SPP or investigating the possibilities of instalments instead of cash payments,

b) By increasing the amount of wood saved by the SPP owners, it is necessary to investigate the ways of increasing the wood raw material that can be transferred from personal fuel allocations to market sales.

Undoubtedly, it is possible to repeat the above analysis not only in terms of GDoF, but also taking into account the savings in LPG consumption of a country dependent on foreign energy in terms of energy. In 
this case, the benefits of the country; it is necessary to add "the price paid for the import of the saved gas amount" and to the costs "losses arising from the reduction of the taxes obtained by the public through gas sales" should be added to the costs. However, although these figures are not known; It should be considered that the amount paid for imports will be more than the amount obtained through taxation and that larger $\mathrm{P} / \mathrm{M}$ ratios may be found.

\section{4- Conclusion}

DoFVR has experienced various organizational and management differences since its establishment. Today; It carries out its activities as a Department under the GDoF in Turkey. Since its establishment, it has implemented various social and economic personal loans and economic cooperative loan projects. For the social loans applied, there is no economic analysis projects other than the benefit-cost ratio. On the other hand, an economic analysis is not carried out considering the project implementation results.

At the project planning stage; there is no economic evaluation that takes into account the economic analyzes made according to the predicted data and the process after the realization of the project. Therefore, it is not determined what effect the post-project process has. With this study; For the socially based SPP project of GDoFVA, the benefit-cost ratio created during the project planning phase, the benefit-cost ratio that emerged according to the post-project data and other economic analyzes (net present value and internal profitability ratio) were determined. Economic analyzes were evaluated in terms of both forest villagers and GDoF.

The Benefit Cost Ratio (B/C) made by GDoFVR considering the market price of the SPP projects implemented in the forest villages of the Western Mediterranean Region varies between 1.30-1.80. However, forest villagers make some of their firewood needs obtained from in their own gardens and agricultural activities. Some of other their needs are met by paying from forest areas. A part of the amount of firewood provided by forest villagers from forest areas is obtained legally and some illegally. Due to the convenience provided to the forest villagers by the forestry law numbered 6831 , the forest villagers obtain the firewood raw material to be obtained legally from the forest areas at a discounted price than the market price. When the discounted price is taken into account, the cost- benefit ratio is 0.77 . This benefitcost ratio shows that the project cannot be economical. However, when the costs of the social-purpose SPP project implemented by GDoFVR are calculated use the market prices, the annual return provided by the IRR, the capital itself is $39.29 \%$.

In SPP social projects, 1/6 of the system cost is considered as depreciation (Anonym, 2013/a; Anonym, 2013/b; Anonym, 2017). System costs vary according to years and regions. The income input used for cost-benefit analysis is the market value of the amount of firewood savings. However, the forest villagers meet their firewood needs from the Forestry Enterprise in the Directorate of the Forestry Enterprise that they are affiliated, according to the forest law numbered 6831. The amount and cost of coniferous and leafy firewood in Regional Forestry Directorates are determined annually by the GDoF. It is also stated above for the project period.

Although GDoFVA tends not to make an economic analysis for social projects in general, an analysis based on objective data should be made, considering the economic deprivation of forest villagers who will benefit by investing. The forest villagers who will benefit from the project need to know the dimensions of the cost incurred in return for benefiting from the project, according to the economic analysis. 
As in the example of the SPP project, the benefit-cost ratio $(\mathrm{B} / \mathrm{C})$ in social projects is not an economic indicator by itself. Expense and income elements used in the analysis; It has not being calculated based on accurate and objective factors. For example, the LPG tube economy used by the forest villagers annually is not included in the project accounts. This savings should be counted as an income. The economy for firewood of the forest villager; It should be determined not with market prices, but by considering the prices determined by GDoF for forest villagers. In this case, there will be decreases in the income account.

It is absolutely necessary and obligatory to make economic calculations of social projects. Because; The economic level of forest villagers, who are investors, is very low. For this reason, in the economic analysis to be made; approaches such as partial budget analysis and opportunity cost should be included.

\section{References}

Acun E., 1983. Aydın İli Köylerinin ve Özellikle Orman köylerinin Kalkındırılmaları Üzerine Araştırmalar, İ.Ü. Yayın No: 3141, OF Yayın No: 338, İstanbul.

Akınyele D. O., Rayudu R. K.; Nair N. K. C.; 2015. Global Progress in photovoltaic Technologies and the scenario of devolopment of solar panal plant and modüle performance estimation- Aplication in Nigerya, Reneweable and Sustainabele Energy Reviews 48 (2015) 112,139

Anıl Y.; 1973. Yukarı Çulhalı Köyünün Sosyo-Ekonomik Dokusu, Ormancıllk Araştırma Enstitüsü Müdürlüğü Teknik Bülten Serisi No: 57, Ankara.

Anonym, 1997. ORKÖY Genel Müdürlüğü, İstatistik Daire Başkanlığı, Ankara.

Anonim, 2007. ORKÖY Genel Müdürlüğü, İstatistik Daire Başkanlığı, Ankara.

Anonym, 2013/a. ORKÖY Burdur GES Projesi, Isparta.

Anonym, 2013/b. ORKÖY Isparta GES Projesi, Isparta.

Anonym, 2017. ORKÖY Antalya, GES Projesi, Antalya.

Anonym, 2020. Orman Varlığı Orman Genel Müdürlüğü, Ankara

Awah, B.S.; 1995. The Rural Woman and the Importance of Fuelwood in Household Energy Consumption in the Diamare Division of the Far North Province, Cameroon.

Balçık B., 2003. Yatırım Projelerinin Hazırlanması ve Değerlendirilmesi, Nobel Yayınevi.

Björnsen Gurung, A., Seidl, I., 2017. Identifying green energy options for the Ukrainian Carpathians. In: 125th IUFRO Anniversary Congress. Book of Abstracts, 2017. Freiburg, pp. 93.

Campana P. E., Li H., Zang J., Zang R., Liu J., Yan J.; 2015/a. Economic optimization of photovoltaic water pumping systems for irrigation, Energy Conservation and Management 95 (2015) 32-41. 
Campana P. E., Leduc S., Kim M., Liu J., Kraxner F., McCallum I., Li H., Yan J.; 2015/b. Optimal grassland locations for sustainable photovoltaic water pumping systems in China, 7th International Conference on Applied Energy - ICAE2015, Energy Procedia 75 (2015) 301-307.

Coşgun U., 2005. "Batı Karadeniz Bölgesi Orman İçi Köylerin Sosyo-Ekonomik Yapısı ve Bu Köylerin Kalkındırılmasında Etkili Olan Sosyoekonomik Faktörlerin Çoğul Sayısal Analiz Yöntemleriyle Belirlenmesi”, Batı Karadeniz Ormancılık Araştırma Enstitüsü Müdürlüğü, Teknik Bülten No: 11, Orman bakanlık No: 220, Müdürlük Yayın No: 16, Bolu

Coşgun U., Ok K., Yılmaz E., Telek A., Ay Z., Uzun E.; 2007. “ORKÖY Kaynaklarının Tahsisinde Orman Köylerinin Önceliklerinin Ormanc1lıkta Sosyo-Ekonomik Sorunlar Kongresi” Saptanması-Antalya İli Örneği, Batı Akdeniz Ormancılık Araştırma Enstitüsü Müdürlüğ̈̈ Teknik Bülten No: 28, Antalya

Coşgun U., 2008. "Batı Akdeniz Orman Araştırma Müdürlüğü’nün 50. Yılında Orman-Halk İlişkileri ve Sosyal Ormancılık Araştırmaları", 50. Yıl Etkinliği "Bildiriler", T.C. Çevre ve Orman Bakanlığı Batı Akdeniz Ormanc1lık Araştırma Müdürlüğü, ISBN: 978-605-393-059-4, sayfa: 349-379, Antalya.

Coşgun U., Bekiroğlu S., Telek A.; 2009. "Orman Köylerindeki Tarımsal Kalkınma Kooperatiflerinin Etkinlik Düzeylerinin İrdelenmesi (Antalya İli Örneği)”, Batı Akdeniz Ormancılık Araştırma Müdürlüğü Teknik Bülten No: 46, ANTALYA.

Coşgun U., Güler K. H.; 2015. “ORKÖY Gün Isı Uygulama Sonuçlarının Değerlendirilmesi (Batı Akdeniz Bölgesi Orman Köyleri Örneği)”, 19.8206/2012-2013-2014 Nolu sonuçlanan proje, Anlatya.

Coşgun U., 2016. Türkiye'nin Ormancılık Politikası Serüveni Örgütlenmesi ve Ormancılıkta Kadının Yeri, “OGM Örgütlenme Yapısı ve Uygulamalarının Değerlendirilmesi”, Dönmez Ofset Basım Evi, Sayfa Sayısı 119, ISBN:978-605-64482-5-6

Coşgun U. 2017. Evaluation of solar Energy by the General Directorate of Forest-Village Relations in the South West Region of Anatolia, pages: 961-963, Volume: 3, Number 5, Journal of Environmental Biology, (SCI). DOI : http://doi.org/10.22438/jeb/38/5(SI)/GM-13.

Coşgun U., 2020. Effects of Projects Aimed at Reducing the Consumption of Firewood in Forest Villages by Department of Forest Village Relations (DoFVR): The case study Zonguldak Regional Directorate, Advances in Scientific Research: Engineering and Architecture, ST. Kliment Ohridski University Press Sofia, ISBN 978-954-07-5047-7, chapter 29, pp:526-541.

Cuce E., Harjunowibowo D., Cuce M. P.; 2016. Renewable and sustainable energy saving strategies for greenhouse systems: A compherensive review, Renewable and Sustainable Energy Reviews 64 (2016) 34-59.

Çağlar Y., 1986. Türkiye'de Orman Köyleri ve Kalkındırılmasına Yönelik Etkinlikler. Ankara: MPM Yayınları, No: 340.

Çağlar, Y., 1987. Orman Köylüleri ve Kü̧̈ük Üreticilik Üzerine, 11. Tez Kitap Dizisi No: 7, İstanbul, s. 59-83.

Daşdemir İ., 2003. Sarıkamış ve Oltu Yöresindeki Ormancılık Kooperatiflerinin Kırsal ve Bölge Ormancılığı Açısından Değerlendirilmesi. Z.K.Ü. Bartın Orman Fakültesi, Zonguldak. 
EJFS-Economic analysis in social responsibility projects of forest villages (case of the western Mediterranean region) by Coşgun 2021

Daşdemir İ., Yılmaz A., 2016. Sürdürülebilir Kırsal Kalkınmada ORKÖY’ün Rolü (Samsun Orman İşletme Örneği), pages; 307-317, ISEM2016, 3rd International Symposium on Environment and Morality, 04-06 November 2016, Alanya/Antalya

Daşdemir İ., Yıldıran Ö., 2017. The Effect of ORKÖY Activities on Sustaniable Rural Development (Example of Kütahya Regional Directorate of Foretry, International Confrence on Agriculture, Forest, Food Science and Technologies, pages; 115, Cappodocia, Nevşehir.

De Montalembert, M.R. and J. Clement,1983. Fuelwood Supplies in the Developing Countries. Food and Agriculture Organization of the United Nations, Rome.

DeFries, R.; Pandey, D.; 2010. Urbanization, the energy ladder and forest transitions in India's Emerging Economy, Land Use Policy, 27, 130-138.

Duruöz E., 1975. Demirköy Orman İşletmesinin Orman Köylerinin Ekonomik Yapılarına Olan Katkısı Üzerine Araştırmalar. Ormancılık Araştırma Enstitüsü Yayınları, Teknik Bülten Serisi No:61, 80 Ankara

Duruöz E., Anıl Y., Çoban C., 1976. Orman Köylüsünün Ormancılık Kesiminde ve Orman Bölge Müdürlüklerindeki Kentlerde İşlendirilmesi Olanakları. Ormancılık Araştırma Enstitüsü Yayınları, Teknik Bülten Serisi No:79, 55 Ankar

DPT, 1970. Türk Köyünde Modernleşme Eğilimleri Araştırması, Rapor I, Yayın No: DPT: 860, SPD: 198, Ankara.

DPT, 1971. Türk Köyünde Modernleşme Eğilimleri Araştırması, Rapor III, Yayın No: DPT: 1071, SPD: 233, Ankara.

Geray U., Acun E.; 1980. Orman Köylülerinin Kentlileşmesi ve Orman-köy İlişkileri (Safranbolu Örneği), İ.Ü. Yayın No: 2640, OF Yayın No: 279, İstanbul.

Geray U.,1982. Toplum Ormancılığg1, Türkiyede Toplum Ormancılığı Geliştirme Projesi. Vezirköprü, Kunduz Eğitim Merkezi Seminer Notları, 35-48 Ankara.

Gökçe O. ve Kalaç M. Ö., 1998. Kırsal Gençlikteki Olası Tarımsal Toplum Yapısı Üzerine Bir Araştırma, Türkiye III. Tarım Ekonomisi Kongresi 7-9 Ekim, Ankara, s.196-204, T. C. Ziraat Bankası Kültür Yayın No: 35.

Gökyel A., Ulusoy D., 2016. Tarımsal Sulamada Güneş Enerjisi, DSİ, Teknik Bülten Sayı: 122, Ekim, sayfa: 19-35, Ankara

Gümüş C., 1993. Orman Köyleri Kalkınma Planlarında ve Sosyal Ormancılık Çalışmalarında Çok Boyutlu Analizlerden Yararlanma Olanakları, I. Ormancılık Şurası, 1-5 Kasım Cilt II, s.267- 278, Ankara.

İstanbullu T., 1978. “Türkiye ‘de Yakıt ve Özellikle Yakacak Odun Sorunu Üzerine Araştırmalar”, İ.Ü. Yayın No. 2405, O.F. Yayın No: 251, Çelikcilt Matbaası, İstanbul.

Johnson, F.X.; Tella, P.V.; Israilava, A.; Takama, T.; Diaz-Chavez, R.; Rosillo-Calle, F.; 2010. What Woodfuels Can Do to Mitigate Climate Change. FAO For. Pap. 2010, 1, 1-98. 
EJFS-Economic analysis in social responsibility projects of forest villages (case of the western Mediterranean region) by Coşgun 2021

Kersten, I.; Baumbach, G.; Oluwole, A.F.; Obioh, I.B.; Ogunsola, O.J.; 1998. Urban and rural fuelwood situation in the tropical rain-forest area of south-west Nigeria. Energy, 23, 887-898.

Korkmaz M., Alkan H., 2014. Ormancılık ve Kırsal Kalkınma: Isparta Orman köyleri Örneğinde Bir Değerlendirme. II. Ulusal Akdeniz Orman ve Çevre Sempozyumu Bildiriler Kitabı, 22-24 Ekim 2014, s.1084, Isparta.

Mohesen M. S., Akash B. A.; 1997. Evaluation of domestic solar water heating system in Jordan using analytic hierarchy process. Energy Convers. Manag., 38, pp. 1815-1822.

Odeh, I., Yohanis, Y.G., Norton, B.; 2006. Economic viability of photovoltaic water pumping systems, Solar Energy 80 (2006) 850-860.

Okutucu M. A., Demir M., Ağyürek C., Bilgili A., Güven M., 2012. "Yenilenebilir Enerji Kaynaklarından Güneş Enerjisinin, ORKÖY Projelerinde Uygulama Sonuçlarının Araştırılması (Erzurum İli)”, III. Ormancılıkta Sosyo-Ekonomik Sorunlar Kongresi, İstanbul.

Önal P., 2010. “Orman Köylerinde ORKÖY Tarafından Gerçekleştirilen Köy Kalkındırma Projelerinin Uygulama Sonuçlarının Araştırılması (Şile-İstanbul)" İ.Ü. Orman Fakültesi Orman Mühendisliği Bölümü Yüksek Lisans Tezi (Yayınlanmamış), İstanbul.

Önal, P., Bekiroğlu, S., 2011. Orman Köylerinde ORKÖY Tarafından Gerçekleştirilen Köy Kalkındırma Projelerinin Uygulama Sonuçlarının Araştırılması (Şile-İstanbul). İstanbul Üniversitesi, Orman Fakültesi Dergisi, 61 (2): 53-66.

Özkurt A., 1998. İçel İli Orman Köylerinin Sosyo-Ekonomik Yapısı, Sorunları ve Orman Köylerinin Yerinde Kalkındırılması Olanakları, Adana, s. 95.

Soloviy, I., Björnsen Gurung, A., Melnykovych, M., Hewitt, R.J., Maksymiv, L., Bihun, Y., 2018. Stakeholders' attitudes towards green energy innovations as a prerequisite to successful implementation: International experience and lessons learned in the Ukrainian Carpathians. In: 5th Forum Carpaticum 2018: Adapting to Environmental and Social Risk in the Carpathian Mountain Region. Book of Abstracts, pp. 64-65.

Soloviy, I.; Melnykovych, M.; Gurung, A., B.; R., J., Hewitt; Ustych, R.; Maksymiv, L.; Brang, P.; Meessen, H.; Kaflyk, M.; 2019. Innovation in the use of wood energy in the Ukrainian Carpathians: Opportunities and threats for rural communities, Forest Policy and Economics 104 (2019) 160-169.

Spertino F., Leo P., Cocina V.; 2013. Economic analysis of investment in the rooftop photovoltaic systems; Alongterm resarch in tje two main markets, Renewable and Sustainable Energy Reviews 28 (2013) 531-540

Taraklı D.;1982. Mudurnu İlçesi Orman Köyleri (Tarım İşletmelerinin Ekonomik Analizi ve İlçe İçin Doğrusal Programlama Yöntemi ile Optimum İşletme Planlarının Saptanması), Ankara.

TOD, 2019. Türkiye Ormancılığı 2019, TOD yayın No:27, Ankara.

Tolunay A., 1992. Neden sosyal ormancılık ve nasıl bir ORKÖY?, Orman Bakanlığı Dergisi, 1-5, 1419.

Tolunay A., 1998. Sosyal Ormancılık ve Türkiye Açısından Önemi, İstanbul Üniversitesi Fen Bilimleri Enstitüsü, Doktora Tezi (Yayınlanmamış) 261s, İstanbul. 
EJFS-Economic analysis in social responsibility projects of forest villages (case of the western Mediterranean region) by Coşgun 2021

Tolunay A., Korkmaz M., 2005. 35. Kuruluş Yılında ORKÖY, I. Çevre ve Ormancılık Şurası, 22-24 Mart 2005, s. 1575-1582, Antalya

Türker M. F., Toksoy, D., 1992. Devlet ormanlarından odun hammaddesinin yakacak odun amacıyla tüketilmesi probleminin çözüm yolları. Çevre Dergisi, Ekim-Kasım-Aralık Sayı 5, Sayfa 5-8.

Türker M. F., 1992. "Maçka Devlet Orman İșletme Müdürlüğü Ormanlarından Odun Hammaddesinin Yakacak Odun Amaciyla Tüketilmesinin Sosyo-Ekonomik Analizi”, KTÜ Fen Bilimleri Enstitüsü Doktora Tezi (Yayınlanmamıştır) Trabzon.

Ullah, S.; Noor, R.S.; Abid, A.; Mendako, R.K.; Waqas, M.M.; Shah, A.N.; Tian, G. 2021. Socio- Economic Impacts of Livelihood from Fuelwood and Timber Consumption on the Sustainability of Forest Environment: Evidence from Basho Valley, Baltistan, Pakistan. Agriculture, 11, 596. https://doi.org/10.3390/ agriculture 11070596

Uzun E., 2008. Gündoğmuş İlçesi ORMAN Köylerinin ve Bu Köylerdeki Tarım İletmelerinin SosyoEkonomik Yapılarının Belirlenmesi, Teknik Bülten No: 32, Antalya.

Y1lmaz S. A.; 2014. Green Jobs and Their Potential in Renewable Energy in Turkey, Ministry of Development, General Directorate of Social Sectors and Coordination, Publication No: 2887, Ankara.

Wang Y., Zhao L., 2006. Economic Analysis of solar water heater in GuangZhou, Policy for energy efficiency and comfort, Vol.VII-4-4, Chine

Win, Z., C.; Mizoue, N.; Ota, T.; Kajisa, T.; Yoshida, S.; 2018. Consumption Rates and Use Patterns of Firewood and Charcoal in Urban and Rural Communities in Yedashe Township, Myanmar, Forests, 9, 429; doi:10.3390/f9070429

Submitted: 10.08 .2021

Accepted: 02.11.2021 